\title{
Krill oil extract suppresses cell growth and induces apoptosis of human colorectal cancer cells
}

\author{
Abilasha Gayani Jayathilake', Paul Vincent Senior ${ }^{2}$ and Xiao Qun Su ${ }^{1 *}$
}

\begin{abstract}
Background: Colorectal cancer (CRC) is the third most common cancer in the world. The current available treatments for CRC include surgery, chemotherapy and radiotherapy. However, surgery is only useful when the disease is diagnosed at the earlier stage. Chemotherapy and radiotherapy are associated with numerous side effects that decrease the patients' quality of life. Safer, effective alternatives, such as natural compounds, to chemotherapy are desirable. This study assessed the efficacy of free fatty acid (FFA) extract of krill oil on three human CRC cells lines.

Methods: HCT-15, SW-480 and Caco-2 cells were treated with the FFA extracts of krill oil and fish oil for $48 \mathrm{~h}$ while treatments with the bioactive omega-3 polyunsaturated fatty acids (LC n-3 PUFA) of these marine oils, eicosapentaenoic acid (EPA, C20:5n-3) and docosahexaenoic acid (DHA, C22:6n-3) in comparison with a n-6 PUFA, arachnoid acid (AA, C20:4n-6) were up to $72 \mathrm{~h}$ at the concentrations of 50, 100, 150 and $200 \mu \mathrm{M}$. Effects of all the treatments on cell proliferation were assessed using a water-soluble tetrazolium-1 (WST-1) assay kit at 24, 48 and $72 \mathrm{~h}$. Effects of FFA extract of krill oil and EPA on apoptosis and mitochondrial membrane potential were determined using commercial kits after $48 \mathrm{~h}$ of treatment.
\end{abstract}

Results: Krill oil extract inhibited cell proliferation of all three cell lines in the similar manner as fish oil extract. A significant cell apoptosis and increase in mitochondrial membrane potential were observed after the treatment with krill oil extract. EPA at the concentration of $200 \mu \mathrm{M}$ reduced significantly the proliferation of HCT-15 and SW-480 at 24, 48 and $72 \mathrm{~h}$. In addition, EPA treatment (100 and $200 \mu \mathrm{M}$ ) resulted in significant cell apoptosis in all three cell lines. No significant changes were observed after treatment with DHA and AA.

Conclusions: Our results indicate that the FFA extract of krill oil maybe an effective chemotherapeutic agent to suppress proliferation and induce apoptosis in CRC cells through its bioactive constitute EPA. Although the exact mechanism of the pro-apoptotic properties of krill oil extract is unclear, mitochondrial pathway seems to be implicated.

Keywords: Krill oil extract, Eicosapentaenoic acid, Docosahexaenoic acid, Human colorectal cancer cells

Abbreviations: AA, Arachnoid acid; ATCC, American tissue culture collection; CRC, Colorectal cancer; DHA, Docosahexaenoic acid; DMEM, Dulbecco's modified eagle's medium; DMSO, Dimethyl sulfoxide; DPA, Docosapentaenoic acid; EPA, Eicosapentaenoic acid; FAME, Fatty acids methyl esters; FCS, Foetal calf serum; FFA, Free Fatty Acids; FID, Flame ionization detector; GC, Gas chromatography; HEPES, 4-2- hydroxyethyl -1piperazineethanesulfonic; LC n-3 PUFA, Long chain n-3 PUFA; MMP, Mitochondrial membrane potential; MRPs, Multidrug resistances-associated proteins; MUFA, Monounsaturated fatty acids; n-6, Omega 6; PBS, Phosphate (Continued on next page)

\footnotetext{
* Correspondence: xiao.su@vu.edu.au

${ }^{1}$ Centre for Chronic Disease, College of Health and Biomedicine, Victoria

University, P.O. Box 14428, Melbourne, VIC 8001, Australia

Full list of author information is available at the end of the article
} 
(Continued from previous page)

buffered saline; PGE2, Prostaglandin E2; PGE3, Prostaglandin E3; PUFA, Polyunsaturated fatty acids; ROS, Reactive oxygen species; SD, Standard deviation; SEM, Standard error of mean; SFA, Saturated fatty acids; WST-1, Water soluble tetrazolium-1

\section{Background}

Colorectal cancer (CRC) is the third most common cancer in men and women, accounting for approximately $9 \%$ of mortality caused by cancer each year $[1,2]$. The initiation of CRC is a complex and multifactorial process that is associated with progressive accumulation of genetic and epigenetic alterations, and these transform normal colonic/rectal mucosa into invasive metastatic carcinoma [3, 4]. Among many factors associated with the development of colorectal cancer, more than $70 \%$ of CRC patients diagnosed are sporadic, and environmental factors have been the main cause for the majority of incidence [3]. Diet is one of the main environmental factors, with $90 \%$ of the CRC reported to be associated with high intake of saturated fat, red meat, n- 6 polyunsaturated fatty acids (PUFA), and low intake of fibres and vitamins [5].

The current available treatments for CRC include surgery, chemotherapy and radiotherapy $[3,6]$. However, surgery is only curative when the disease is diagnosed at an earlier stage. Chemotherapy and radiotherapy are associated with numerous side effects, such as myelosuppression, mucositis, dermatitis and diarrhoea, thus these treatments have a significant impact on patient's quality of life $[6,7]$. In recent years, the potential role of nutrients as preventive/therapeutic agents has been one of the main foci in cancer research [6-8].

Fish oil is a rich source of long chain omega- 3 polyunsaturated fatty acids (LC n-3 PUFA), mainly eicosapentaenoic acid (EPA, C20:5n-3) and docosahexaenoic acid (DHA, C22:6n-3). EPA and DHA have demonstrated preventive and therapeutic effects on the CRC $[9,10]$. Epidemiological studies showed that increased consumption of fish oil or LC n-3 PUFA is inversely correlated with CRC incidence $[11,12]$. Studies have shown that LC n-3 PUFA have growth-inhibitory and pro-apoptotic effects on colon cancer cells such as HT-29, HCT-116, SW-480 and Caco-2 [13-15]. Animal studies showed that fish oil supplementation reduced the number and size of polyps and suppressed the growth of cancer xenografts in nude mice [16-20].

Several sustainable alternatives of fish oil have been identified to meet the demand for LC n-3 PUFA during last decades and one of these is the krill oil. Krill oil is extracted from Euphasia superba, a crustacean species similar to shrimp found in the Southern Ocean [8]. Apart from the LC n-3 PUFA, EPA and DHA, krill oil also contains astaxanthin (provitamin E), flavonoids and vitamin-A. Different from fish oil, in the krill oil, EPA and DHA are bound to the phospholipids [21, 22]; while in the fish oil they are mainly bound to the triglycerides [23]. Studies have shown that the phospholipids bound n-3 PUFA can penetrate through cell membrane efficiently [24] than those bound to glycerol in triglycerides thus could potentially lead to better health outcomes $[8,25]$.

Preliminary studies have shown that krill oil has anticancer properties such as inhibition of proliferation of osteosarcoma and colon cancer SW-480 cells $[8,26]$. However, little information is available on the effect of krill oil on other CRC cells, and no data are available on its impact on cell apoptosis. Apoptosis is a key process of programmed cell death, which plays a crucial role in maintaining cellular homeostasis between cell division and cell death [27]. Alterations in the mitochondrial membrane potential (MMP) and permeability could trigger the release of cytochrome $c$ into the cytosol, which activates caspases that in turn, induce apoptosis [11]. In the present study, we investigated the effects of free fatty acid (FFA) extract from krill oil in comparison with that from fish oil on three human CRC cell lines HCT-15, SW-480 and Caco-2. In addition, effects of EPA and DHA on these cells are also assessed. To the best of our knowledge, this is the first study assessing the impacts of krill oil on cell apoptosis and investigating whether the apoptotic process is mediated by changes in MMP.

\section{Methods}

\section{Cell lines and culture conditions}

The human colon adenocarcinoma cell lines of HCT15, SW-480 and Caco-2 were obtained from the American Tissue Culture Collection (ATCC) Manassas, VA, USA. HCT-15 and SW-480 cell lines were maintained in RPMI 1640 medium (SAFCO) (Sigma Aldrich, Castle Hill, NSW) supplemented with foetal calf serum (FCS, $10 \%$ ) (Hyclone Quantum Scientific, Clayton South, VIC), glutamine (10 mM), 4-2hydroxyethyl-1-piperazineethanesulfonic acid (HEPES $10 \mathrm{mM})$ and penicillin $(100 \mathrm{U} / \mathrm{ml}) /$ streptomycin $(100 \mu \mathrm{g} / \mathrm{ml})$ (Sigma Aldrich, Castle Hill, NSW). The Caco-2 cell line was maintained in Dulbecco's Modified Eagle's Medium (DMEM) (Sigma Aldrich, Castle Hill, NSW) supplemented with 20\%FCS and penicillin $(100 \mathrm{U} / \mathrm{ml}) /$ streptomycin $(100 \mu \mathrm{g} / \mathrm{ml}), 2 \mathrm{mM} / \mathrm{L}$ glutamine, $0.1 \mathrm{mM}$ non-essential amino acids. Cells were grown at $37{ }^{\circ} \mathrm{C}$ in $5 \% \mathrm{CO}_{2}$ humidified atmosphere. 


\section{Extraction of free fatty acids from oils and fatty acid solution preparation}

Krill oil and fish oil (Swisse Wellness Pty Ltd., Victoria, Australia) were purchased from the local Chemist. Free fatty acids were extracted from krill oil and fish oil following the hydrolysis (saponification) method of Salimon et al. [28]. The extracts were dissolved in the Dimethyl Sulfoxide (DMSO) and stored at $-20{ }^{\circ} \mathrm{C}$. The final treatment solutions contained $1 \% \mathrm{DMSO}$ as solvent. Individual PUFA including EPA, DHA and Arachnoid Acid (AA) were purchased from Nu-Chek-Prep, Elysian, USA. Fatty acid solutions were made up by dissolving the individual fatty acid in ethanol. The final treatment solutions contained $<0.1 \%$ ethanol as solvent.

\section{Cell proliferation assays}

A water-soluble tetrazolium-1 (WST-1) assay kit (Roche Diagnostics $\mathrm{GmbH}$, Germany) was used to determine the proliferative potential of cancer cells. Cells were seeded and cultured at $1 \times 10^{4}$ cells per well in 96-well plates for $24 \mathrm{~h}$, and then treated with individual PUFA solutions for 24,48 or $72 \mathrm{~h}$; or free fatty acid extract solutions of oils (krill oil or fish oil) for $48 \mathrm{~h}$. All treatments were performed in quadruplicates. For PUFA treatments, three concentrations of each fatty acid were used including $50 \mu \mathrm{M}, 100 \mu \mathrm{M}$ and $200 \mu \mathrm{M}$. $0.1 \%$ ethanol was used as a vehicle control. Additional assays were performed to observe the effects of various EPA concentrations $(100 \mu \mathrm{M}, 120 \mu \mathrm{M}, 140 \mu \mathrm{M}, 160 \mu \mathrm{M}, 180 \mu \mathrm{M}$ and $200 \mu \mathrm{M})$ on cell proliferation of HCT-15 cells after $48 \mathrm{~h}$ of treatment. The treatment concentrations of free fatty acid extract of oils (krill oil or fish oil) are 0.03, $0.06,0.12$ or $0.24 \mu \mathrm{L} / 100 \mu \mathrm{L}$ well. $1 \%$ DMSO was used as a vehicle control. Non -treated cells were used as a negative control in all experiments. $10 \mu \mathrm{L}$ WST-1 reagent was added to each well after respective treatment time points and incubated at $37{ }^{\circ} \mathrm{C}$ for one hour. Cell proliferation was measured using a microplate reader (Varioskan Flash, Thermo Scientific) at the absorbance of $450 \mathrm{~nm}$.

\section{Apoptosis assay}

Cells $\left(1 \times 10^{3}\right.$ cells/well) were grown in 96-well plates with a clear flat bottom (Corning ${ }^{\mathrm{TM}} \operatorname{Costar}^{\mathrm{TM}}$ 3603, USA) at $37{ }^{\circ} \mathrm{C}$ for $24 \mathrm{~h}$. They were then treated by EPA at $100 \mu \mathrm{M}$ or $200 \mu \mathrm{M}$, free fatty acid extract from krill oil at $0.12 \mu \mathrm{L} / 100 \mu \mathrm{M}$ well for $48 \mathrm{~h}$. After removing the media, cells were washed twice by using PBS. Apoptosis/ Necrosis was detected using the commercial kit (ab176749, Abcam, Cambridge, England). Cells were examined under the fluorescence microscope (Olympus $1 \times 81$ ). The apoptosis was determined by comparing the number of treated cells against the control. Each experiment was performed in quadruplicates, and it was carried out three times for each cell line.

\section{Mitochondrial membrane potential JC-10 assay}

Cells were seeded at $20 \times 10^{4}$ cells/well in the clear bottom 96-well plates (Corning ${ }^{\mathrm{Tm}}$ Costar $^{\mathrm{TM}}$ 3603, USA) to incubate for $24 \mathrm{~h}$ at $37{ }^{\circ} \mathrm{C}$. Then the media was added with EPA at $100 \mu \mathrm{M}$ or $200 \mu \mathrm{M}$, or free fatty acid extract from krill oil at $0.12 \mu \mathrm{L} / 100 \mu \mathrm{L}$ well and incubated for $48 \mathrm{~h}$. The mitochondrial membrane potential was measured by using the JC-10 mitochondrial membrane potential assay kit (ab 112134) as per the manufacturer's instructions (Abcam). In brief, $50 \mu \mathrm{L}$ of JC-10 reagents was added to each well after the treatment, and incubated for one hour at $37{ }^{\circ} \mathrm{C}$ in dark. $50 \mu \mathrm{L}$ of assay buffer was added to each well. Fluorescence intensity was measured using a microplate reader (Varioskan Flash, Thermo Scientific) at Ex/Em $=485 / 520 \mathrm{~nm}$ and $\mathrm{Ex} / \mathrm{Em}=$ $540 / 570 \mathrm{~nm}$. The mitochondrial membrane potential changes were measured as the ratio between aggregate $(\mathrm{Em} 520 \mathrm{~nm})$ and monomeric forms (Em $570 \mathrm{~nm}$ ) of JC10. The increases of the ratio indicate the mitochondrial membrane depolarisation. Quadruplicates were performed for each treatment and two individual experiments were conducted for each cell line.

\section{Analysis of fatty acid composition in EPA treated cancer cells}

HCT-15 cells were seeded at a density of $5 \times 10^{5}$ cells/ well in 6-well plates and incubated for $24 \mathrm{~h}$ at $37{ }^{\circ} \mathrm{C}$. EPA $(100 \mu \mathrm{M}$ or $200 \mu \mathrm{M})$ was added to each well. Each treatment was performed in triplicate. After $48 \mathrm{~h}$ incubation, cells were collected into $15 \mathrm{ml}$ Falcon tubes and centrifuged at $1300 \mathrm{rpm}$ for $6 \mathrm{~min}$ (Thermo Scientific Haraeus, Megafuge 40). The cell pellets were then used to extract fatty acid methyl esters (FAME) using a modified transesterification method of Lepage and Roy [29]. Briefly, cell pellets were mixed with $2 \mathrm{~mL}$ of internal standard, heneicosanoic acid, C21:0 (180 $\mu \mathrm{g})(\mathrm{Nu}-\mathrm{Chek}$ Prep, Inc., Elysian, MN) in methanol:toluene (4:1 (v/v)). $200 \mu \mathrm{L}$ of acetyl chloride was then added and the mixture was incubated for $1 \mathrm{~h}$ at $100{ }^{\circ} \mathrm{C}$ to form FAME. $5 \mathrm{~mL}$ of $6 \%$ potassium carbonate $\left(\mathrm{K}_{2} \mathrm{CO}_{3}\right)$ in distilled water was then added and the blend was thoroughly vortexed prior to centrifugation at $3000 \times g$ (Sigma 3-30 K) for $10 \mathrm{~min}$ to separate the layers. The top toluene-rich layer was removed and evaporated to dryness under nitrogen. $200 \mu \mathrm{L}$ of petroleum ether was added and the resulting FAME was separated by the Gas Chromatography (GC). The GC (Varian Star 3400Cx, Agilent Technologies, CA, USA) was equipped with a SGE BPX 70 capillary column $(60 \mathrm{~m} \times 0.25 \mathrm{~mm}$ internal diameter, $0.25 \mu \mathrm{m}$ film thickness) (SGE Analytical Science, Melbourne, Australia), and a flame ionization detector 
(FID). For each sample, $2 \mu \mathrm{L}$ was injected in splitting mode (1:10) with helium as the carrier gas. Fatty acids were identified by comparison with a standard FAME mixture, GLC reference standard 403 (Nu-Chek Prep, Inc., Elysian, MN). The composition of each fatty acid was calculated as a percentage of the total amount of fatty acids in the mixture.

\section{Statistical analysis}

All the data were analysed using SPSS 22 software. Mixed model ANOVA was used to determine the significance between treatments. The significance of repeated measure at different time point was analysed using one way ANOVA. $p<0.05$ was considered significant. The results were expressed as mean \pm SD in Table or mean \pm SEM in Figures.

\section{Results}

\section{Effects of PUFA on the proliferation of cancer cells}

Human colon cancer cells of HCT-15 and SW-480 cell lines treated with $200 \mu \mathrm{M}$ of EPA showed a significant reduction of cell proliferation at all three time points (24, 48 and $72 \mathrm{~h}$ ) compared to cells treated with ethanol (Fig. 1). It inhibited HCT-15 cell proliferation by $76 \pm$ $0.19 \%, 94 \pm 0.06 \%$ and $91 \pm 0.06 \%$ at 24,48 and $72 \mathrm{~h}$ respectively (Fig. 1a). For SW-480 cells, the inhibitory effect was even more remarkable, with $98 \pm 0.01 \%, 100 \pm$ $0.02 \%$ and $99 \pm 0.01 \%$ reduction in cell proliferation being observed at the three time points respectively (Fig. 1b). However, treatment with lower EPA concentration $(50 \mu \mathrm{M}$ and $100 \mu \mathrm{M})$ did not show positive results. Furthermore, no significant effects were recorded after the treatment with DHA or AA. Caco- 2 cells did not respond to the treatment of EPA and other two fatty acids at any concentrations and any time points.

To investigate the dose dependent effects of EPA on cell proliferation, four concentrations of EPA solution ranged from $120 \mu \mathrm{M}$ to $180 \mu \mathrm{M}$ in addition to 100 and $200 \mu \mathrm{M}$ were used to treat HCT-15 cells. As shown in Fig. 2, a significant reduction of cell growth $(p<0.01)$ after $48 \mathrm{~h}$ of treatment with $160 \mu \mathrm{M}$ and $180 \mu \mathrm{M}$ EPA was observed. Cell proliferation has been reduced by $60 \%$ and $95 \%$ respectively compared with $97 \%$ reduction with $200 \mu \mathrm{M}$ EPA treatment.

\section{Effects of krill oil extract on the proliferation of cancer cells}

HCT-15 cancer cells treated with FFA extracted from krill oil for $48 \mathrm{~h}$ at the concentrations from 0.06 to $0.24 \mu \mathrm{L} / 100 \mu \mathrm{L}$ significantly reduced cell proliferation compared to DMSO control as shown in Fig. 3a. Similarly, FFA extracted from fish oil also inhibited cell proliferation but started at the relatively lower concentration $(0.03$ to $0.24 \mu \mathrm{L} / 100 \mu \mathrm{L})$. The percentage of cell inhibition by krill oil extract ranged from 94 to $96 \%$, and by fish oil extract from 90 to $96 \%$. SW -480 cells responded to treatment with FFA extract of krill oil and fish oil in the same manner as HCT-15 cells (results not shown). For Caco-2 cells only the high concentration of FFA extract of krill oil $(0.24 \mu \mathrm{L} / 100 \mu \mathrm{L})$ inhibited cell proliferation significantly $(p<0.01)$, and this may be due to the presence of multidrug resistanceassociated proteins in the cells (MRPs) [30]. While lower concentrations of FFA extract of fish oil $(0.06 \mu \mathrm{L} / 100 \mu \mathrm{L}$ well) exhibited better inhibitory effects.

\section{Effects of krill oil FFA and EPA on apoptosis}

As shown in Fig. 4, treatment with EPA at 100 and $200 \mu \mathrm{M}$ and FFA extract of krill oil at $0.12 \mu \mathrm{L} / 100 \mu \mathrm{L}$ well for $48 \mathrm{~h}$ resulted in a significantly high apoptosis compared to the control in all three colorectal cancer cell lines. In addition, cell necrosis increased significantly after $48 \mathrm{~h}$ treatment with $200 \mu \mathrm{M}$ EPA and $0.12 \mu \mathrm{L} /$ $100 \mu \mathrm{L}$ well with FFA extract of krill oil in HCT-15 cells. For SW-480 cells, necrosis was promoted slightly by $200 \mu \mathrm{M}$ EPA only $(p<0.01)$ while none of the treatments affected the cell necrosis in Caco-2 cells.

\section{Effects of krill oil FFA and EPA on MMP of cancer cells}

The three cell lines HCT-15, SW-480 and Caco-2 were treated with EPA at $100 \mu \mathrm{M}$ and $200 \mu \mathrm{M}$, and FFA extract of krill oil at $0.12 \mu \mathrm{L} / 100 \mu \mathrm{L}$ well for $48 \mathrm{~h}$ to measure the mitochondrial membrane potential (MMP) change of the cancer cells. Mitochondrial membrane depolarisation in all three cell lines was significantly higher after treatment with FFA extract of krill oil compared to the control. However, no significant change was observed after EPA treatment (Fig. 5).

\section{PUFA profile of HCT-15 cells after EPA treatment}

HCT-15 cells treated with EPA at concentrations of $100 \mu \mathrm{M}$ and $200 \mu \mathrm{M}$ for $48 \mathrm{~h}$ resulted in significant increases in EPA incorporation in the cancer cells (Table 1). EPA treated cells also showed a significantly lower level of AA, especially in cells treated with $200 \mu \mathrm{M}$ EPA. In addition, $100 \mu \mathrm{M}$ EPA treatment resulted in a significant increase in DPA (22:5n-3) level in the cells. Consistently a higher n-3/n-6 ratio was observed in EPA treated cells at both concentrations.

\section{Discussion}

The main objective of the current study was to investigate the effect of krill oil extract on three human CRC cell lines, HCT-15, SW-480 and Caco-2 cells. The study has demonstrated that FFA extract of krill oil can inhibit cell proliferation significantly in HCT-15 and SW-480 cells, and induced cell apoptosis in all three cell lines. The anti-proliferative effect of krill oil is consistent with 

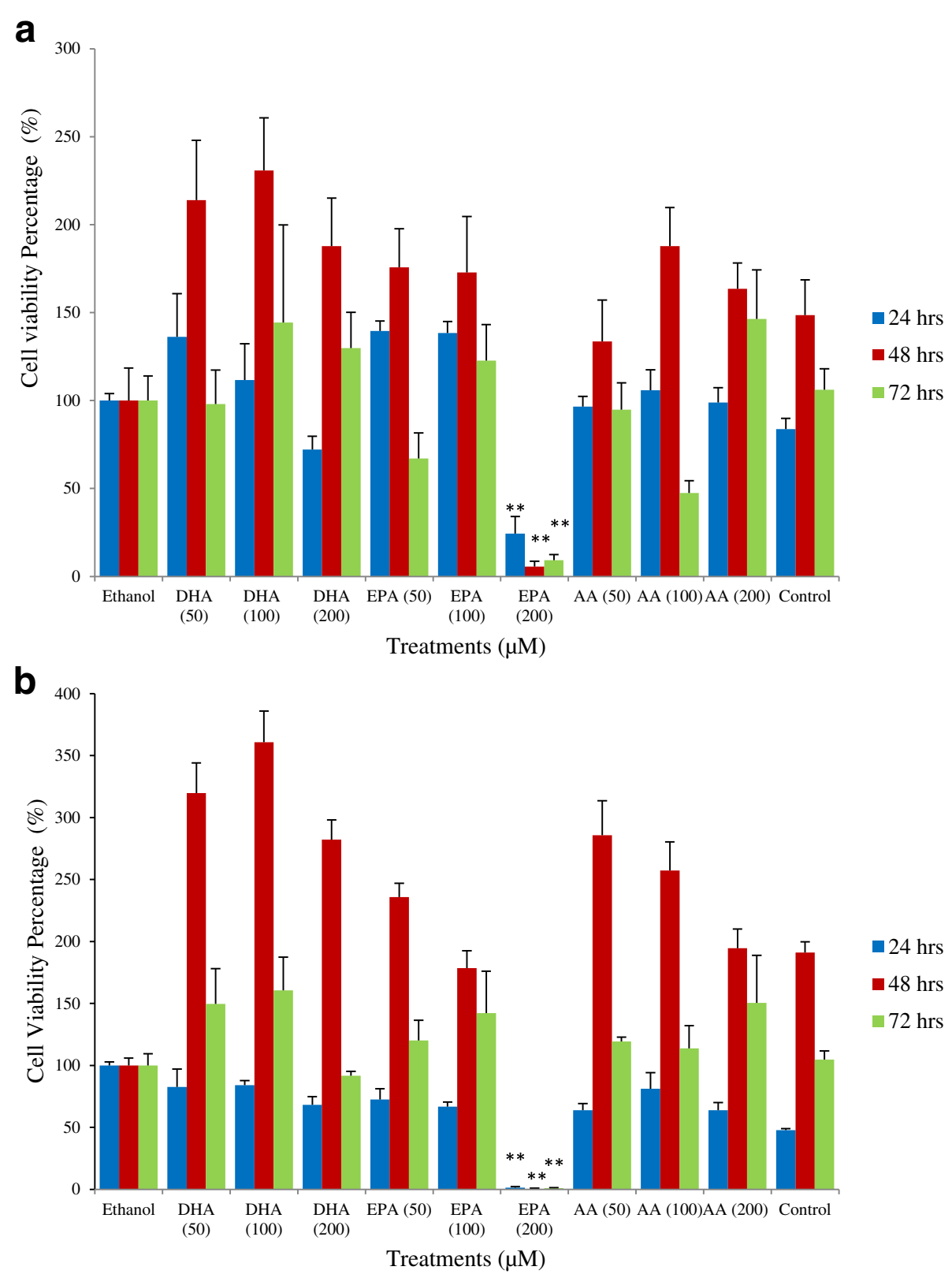

Fig. 1 Proliferation of cancer cells after treatment with PUFA. ${ }^{* *}$ indicates a significant difference $(p<0.01)$ compared with ethanol. a HCT-15 cell line; b SW-480 cell line

the previous studies on colorectal cancer and osteosarcoma cells $[8,26]$. Su and co-authors $[8]$ found that the anti-proliferative role of krill oil on osteosarcoma is comparable with 500nM of doxorubicine, a commonly used clinical drug for cancer treatment [31]. The positive outcomes from this study suggest that krill oil may potentially be a useful cancer therapy tool, especially since no adverse effects have been reported with krill oil consumption [23]. Further animal studies are required to confirm the anti-cancer effects of krill oil on CRC in vivo.
It appears likely that the anti-proliferative and proapoptotic effects of krill oil extract may be attributed to the EPA in this marine oil. A number of studies have reported the inhibitory effects of EPA, DHA and fish oil on the growth and development of various cancers in vitro and in vivo $[6,13,32-35]$. In vitro studies showed that treatment with EPA or DHA resulted in growth arrest in various human cancer cells. Various mechanisms underlying the anti-cancer effects of EPA have been proposed. These include the inhibition of production of prostaglandin $\mathrm{E}_{2} \quad\left(\mathrm{PGE}_{2}\right)$ [36], an 


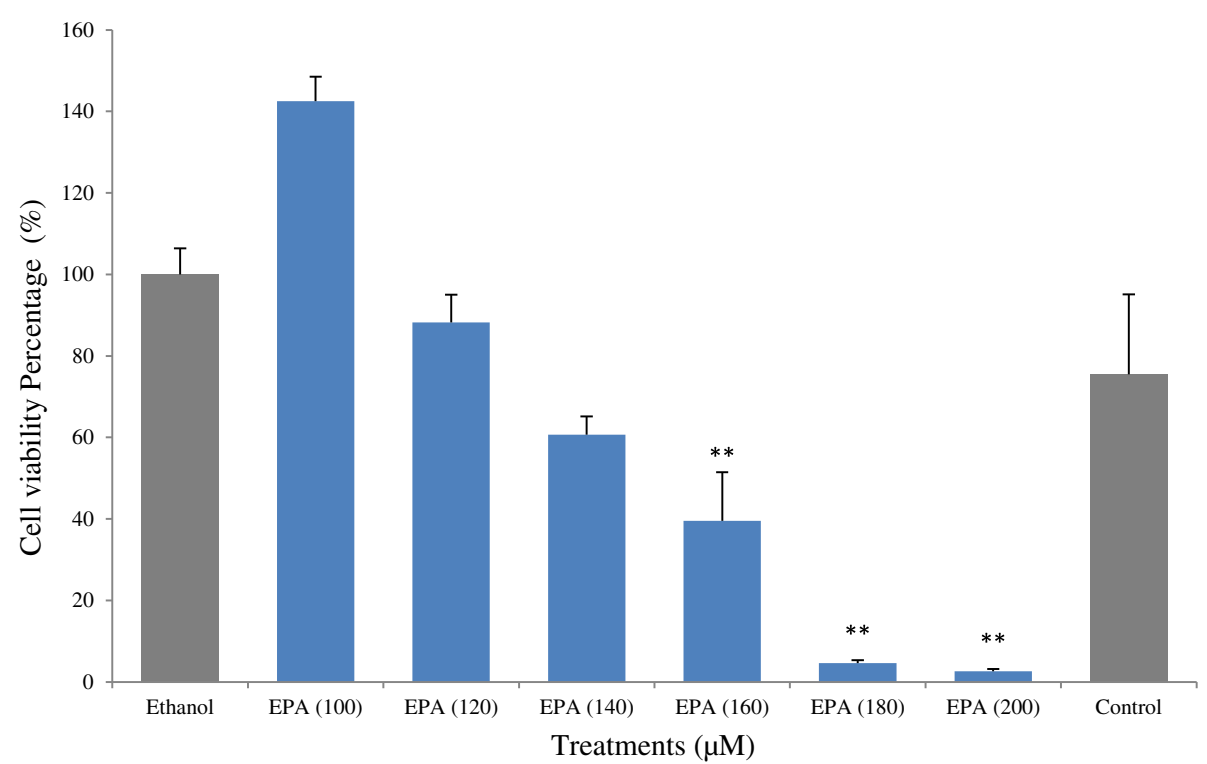

Fig. 2 Proliferation of HCT-15 cells after $48 \mathrm{~h}$ of treatment with EPA. ** indicates a significant difference $(p<0.01)$ compared with ethanol

eicosanoid derived from the AA, which is associated with cell proliferation, differentiation, apoptosis, angiogenesis and metastasis [37, 38]. EPA competes with AA for the metabolic pathway as they are both catalysed by the same enzymes, and therefore when a high level of EPA is in the cells, more eicosanoids derived from EPA $\left(\mathrm{PGE}_{3}\right)$ will be produced. These eicosanoids inhibit the activity of $\mathrm{Akt} / \mathrm{pkB}$ kinase expression that reduces the PGE2 level [5] and have contrasting properties to $\mathrm{PGE}_{2}$, such as anti-inflammatory, anti-proliferation and proapoptosis [19, 39].

In addition, EPA treatment has been found to induce cell apoptosis via arresting cell cycle in pancreatic cancer cells [40]. This reduced the level of anti-apoptotic bcl-2 protein expression in human leukaemia cells [41]. Chi et al. have shown that EPA induced cell apoptosis activation via p53 dependent Fas/FasL pathway in hepatoma cells [42]. The role of EPA in the modulation of gene expression and activation of caspases involved in cancer cell apoptosis has also been reported [43, 44]. Furthermore, Fukui et al. have shown both in vitro and in vivo that the anti-cancer effects of EPA is associated with the cell death resulted from the accumulation of ROS in the cancer cells [17].

Studies have also shown that EPA and DHA induced apoptosis of colon cancer cells through mitochondrial pathway involving a change of mitochondrial membrane potential (MMP), and the release of cytochrome $c$ and other pro-apoptotic factors leading to cell death. In addition, it has been reported that EPA treatment in vitro $[17,45,46]$ and FO supplementation in vivo [47, 48] could increase $\mathrm{ROS}$ and $\mathrm{Ca}^{2+}$ levels in mitochondria and disrupt mitochondrial membrane potential leading to cell apoptosis in various human and rat cancer cells. To investigate whether the proapoptotic effect of EPA and krill oil extract in the present study was through mitochondrial pathway, we evaluated the changes in MMP after $48 \mathrm{~h}$ of treatment. It was found that there was a significant increase in the depolarization of mitochondria membrane in the cells treated with krill oil extract, and this was correlated with the number of apoptotic cells in the three cell lines (Figs. 4 \& 5). However treatment with EPA or DHA did not show significant effect on MMP as krill oil extract (Fig. 5, data on DHA not shown). The results from the current study on MMP suggest that other components of the krill oil extract may play a role in the alteration of MMP, and the EPA induced cell apoptosis was possibly through other mechanisms rather than mitochondrial pathway. Further studies are required to fully understand the mechanisms underlying the pro-apoptotic effects of krill oil extract and whether other mechanistic pathways such as changes in cell cycle, signalling receptors, intracellular $\mathrm{Ca}^{2+}$ balance, and induced stress in endoplasmic reticulum etc. also play a role [49].

Studies have shown the anti-cancer effect of DHA on several cancer cell types including colorectal cells $[13,50,51]$. DHA was found to reduce cell proliferation more efficiently than EPA by Schonberg et al. [52]. In the current study, we have not found significant cell inhibition by DHA at concentrations between $50 \mu \mathrm{M}$ to $200 \mu \mathrm{M}$ in any of the three cancer cell lines. Our results are at discrepancy with the previous report on SW-480 and Caco-2 cells that showed significant inhibition on cell growth after DHA treatment [53]. 


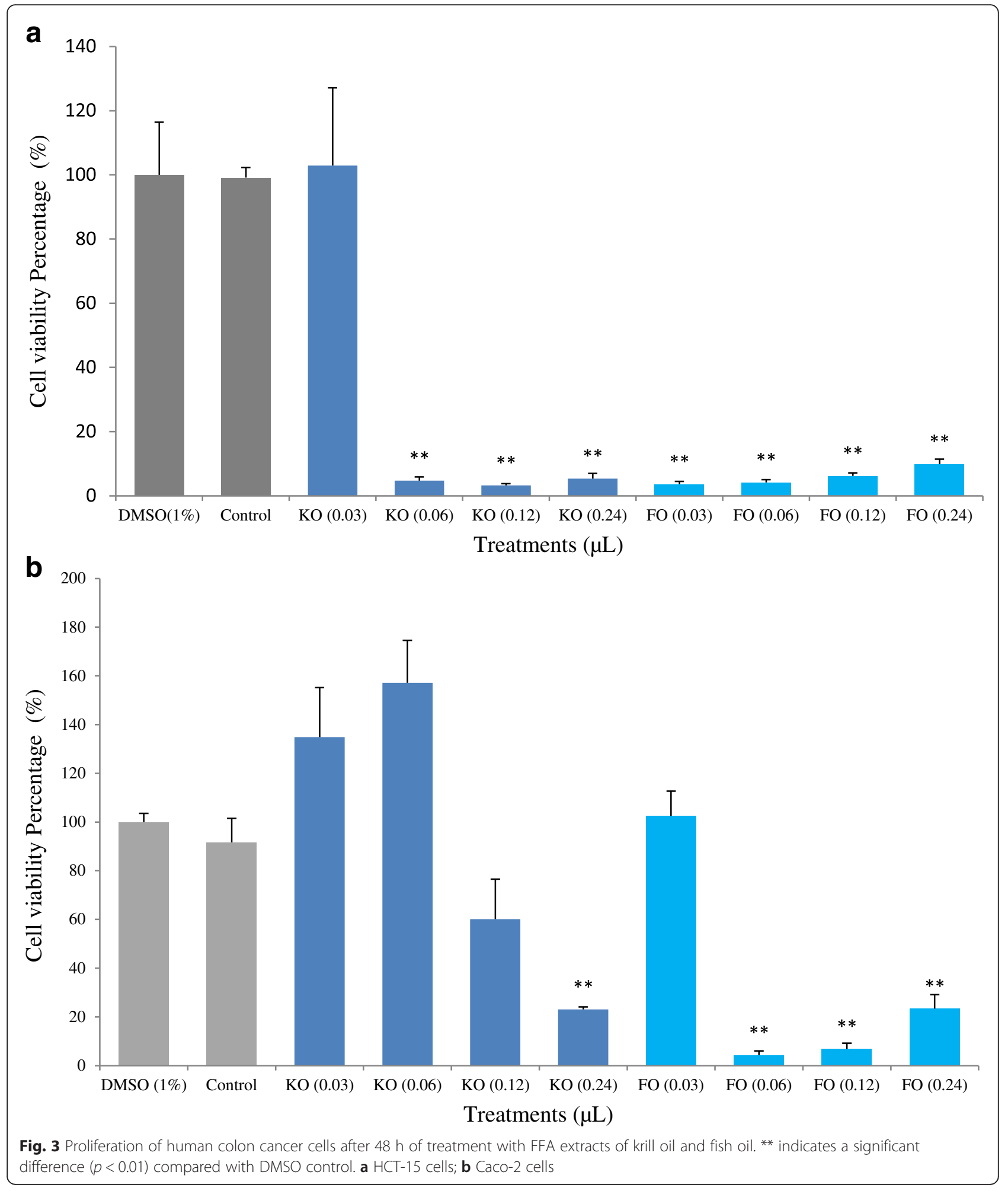

Corsetto et al. have reported that DHA inhibits cell growth at the concentrations higher than $200 \mu \mathrm{M}$ [37]. Schonberg et al. Schonberg SA et al. have found that SW-480 cells are more resistant to DHA treatment [52]. Further study is required to investigate whether higher concentration of DHA can exert anti-cancer effects on HCT-15, SW-408 and Caco-2 cells.

Lipid synthesis is one of the critical functions in cell growth and proliferation. Previous studies have shown that n-3 PUFA induced cell apoptosis is mainly via 

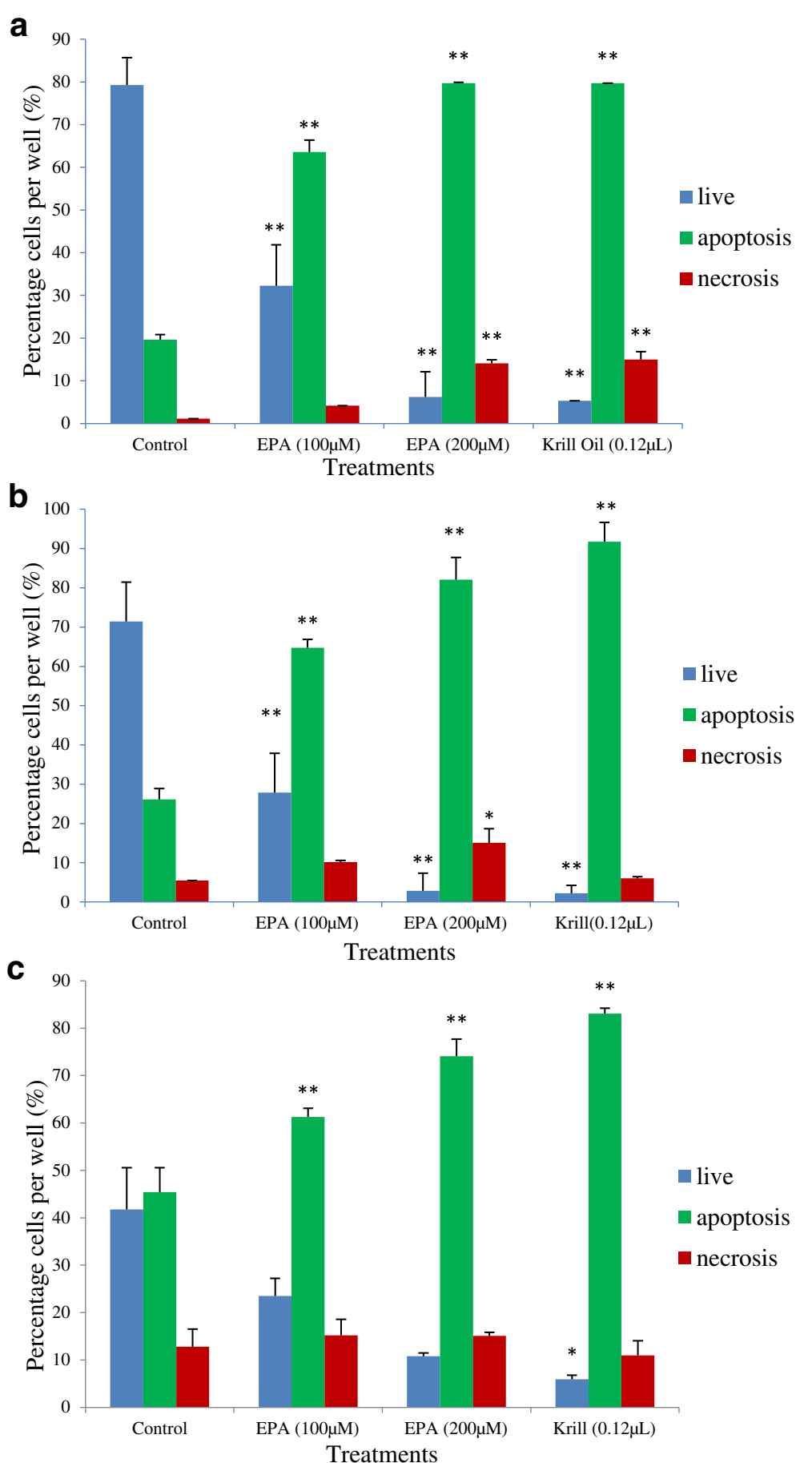

Fig. 4 Apoptosis of human colon cancer cells after $48 \mathrm{~h}$ of treatment with EPA and FFA extract of krill oil. ** indicates a significant difference $(p<0.01)$ compared with the control. a HCT-15 cells; b SW480 cells; c Caco-2 cells

asymmetric lipid disruption in the cell membrane leading to changes in cell membrane structure, signal pathways and control intracellular homeostasis [54-56]. The results of this study have shown that higher concentration of EPA $(200 \mu \mathrm{M})$ effectively reduced the cell proliferation in HCT-15 and SW-480 cells. It also highlighted a significant increase in cellular EPA and n-3 fatty acid levels in the cells treated by EPA, and a significant reduction of AA level after treatment with EPA. Consistently, other studies have also shown that EPA supplementation could significantly increase EPA level in the cells, and that suppressed cell proliferation and 


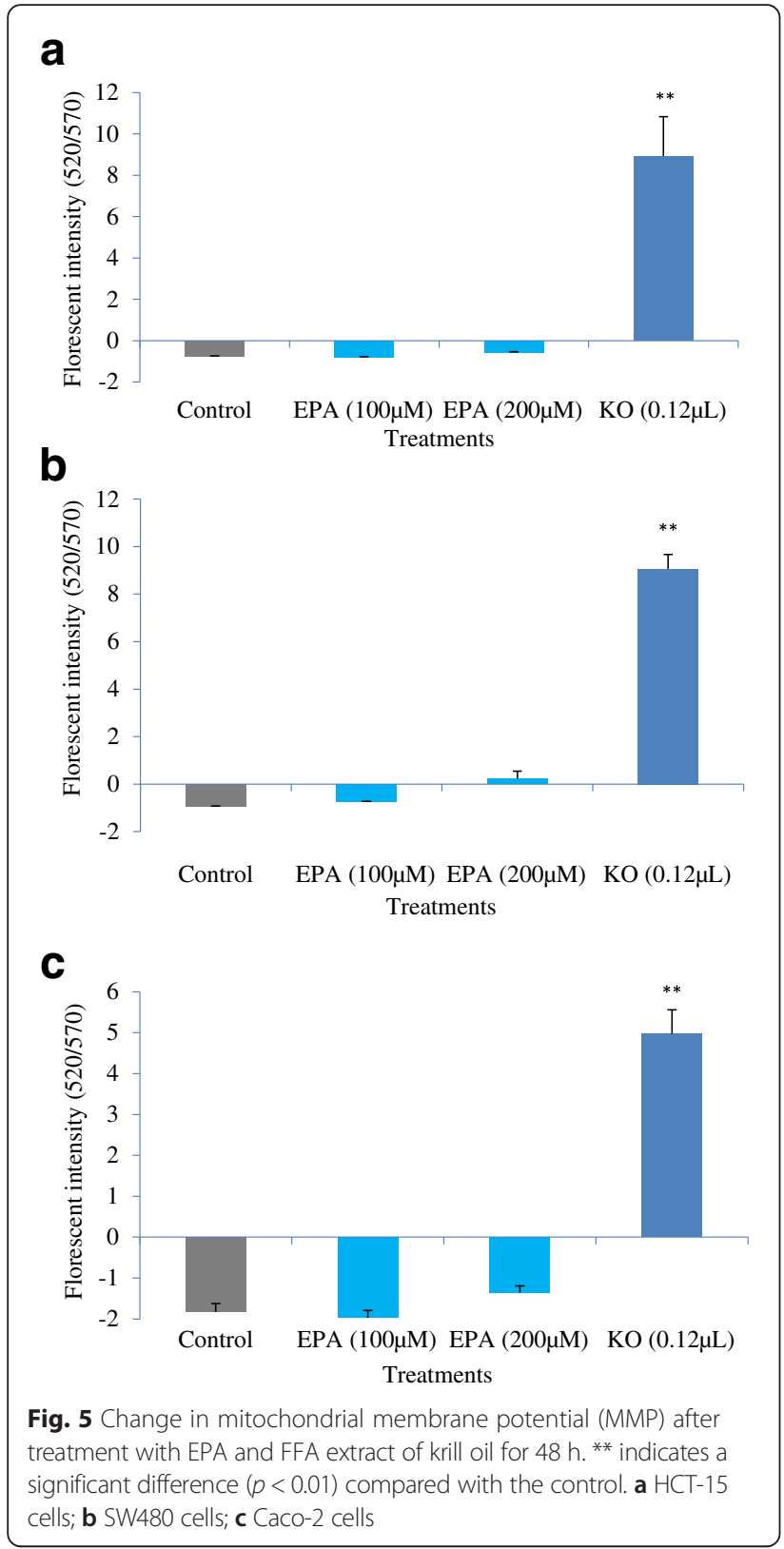

induced apoptosis $[36,57]$. In addition, EPA treatment has significantly increased docosapentaenoic acid (DPA $\mathrm{n}-3)$ at the present study. This is in agreement with the results reported by Calviello [57]. This indicates that EPA, after incorporation into cells, maybe further metabolised through elongation to DPA [8]. DPA is also a long chain n-3 PUFA but its health benefits on cancer and other diseases are limited in comparison with EPA and DHA [58].

The results of this study have shown a significant increase in $n-3 / n-6$ ratio after treatment with EPA at both 100 and $200 \mu \mathrm{M}$. This is consistent with other studies [59], and it may have clinical relevance. The significantly higher $n-3 / n-6$ ratio has been reported to be associated
Table 1 Fatty acid composition of HCT cells treated by different EPA concentrations

\begin{tabular}{lllll}
\hline & Control & Ethanol & EPA $(100 \mu \mathrm{M})$ & EPA $(200 \mu \mathrm{M})$ \\
\hline LA (n-6) & $0.62 \pm 0.04^{\mathrm{a}}$ & $0.59 \pm 0.01^{\mathrm{a}}$ & $0.47 \pm 0.02^{\mathrm{b}}$ & $0.44 \pm 0.01^{\mathrm{b}}$ \\
ALA (n-3) & $0.10 \pm 0.02$ & $0.09 \pm 0.01$ & $0.08 \pm 0.01$ & $0.09 \pm 0.00$ \\
AA (20:4 n-6) & $1.46 \pm 0.12^{\mathrm{a}}$ & $1.44 \pm 0.06^{\mathrm{a}}$ & $0.89 \pm 0.02^{\mathrm{b}}$ & $0.74 \pm 0.06^{\mathrm{b}}$ \\
EPA (20:5 n-3) & $0.25 \pm 0.03^{\mathrm{a}}$ & $0.27 \pm 0.05^{\mathrm{a}}$ & $5.97 \pm 0.11^{\mathrm{b}}$ & $9.57 \pm 0.64^{\mathrm{c}}$ \\
DPA (22:5 n-3) & $0.71 \pm 0.03^{\mathrm{a}}$ & $0.72 \pm 0.01^{\mathrm{a}}$ & $2.75 \pm 0.05^{\mathrm{b}}$ & $1.54 \pm 0.12^{\mathrm{b}}$ \\
DHA (22:6 n-3) & $0.76 \pm 0.03^{\mathrm{a}}$ & $0.71 \pm 0.02^{\mathrm{a}}$ & $0.37 \pm 0.01^{\mathrm{b}}$ & $0.36 \pm 0.01^{\mathrm{b}}$ \\
EPA + DHA & $1.00 \pm 0.05^{\mathrm{a}}$ & $0.98 \pm 0.03^{\mathrm{a}}$ & $6.33 \pm 0.11^{\mathrm{b}}$ & $9.92 \pm 0.63^{\mathrm{c}}$ \\
Total n-3 & $1.81 \pm 0.09^{\mathrm{a}}$ & $1.79 \pm 0.04^{\mathrm{a}}$ & $9.16 \pm 0.16^{\mathrm{b}}$ & $11.55 \pm 0.76^{\mathrm{b}}$ \\
Total n-6 & $2.07 \pm 0.14^{\mathrm{a}}$ & $2.03 \pm 0.06^{\mathrm{a}}$ & $1.36 \pm 0.03^{\mathrm{b}}$ & $1.17 \pm 0.06^{\mathrm{b}}$ \\
n3/n6 & $0.87 \pm 0.25^{\mathrm{a}}$ & $0.88 \pm 0.01^{\mathrm{a}}$ & $6.72 \pm 0.11^{\mathrm{b}}$ & $9.85 \pm 0.69^{\mathrm{c}}$ \\
\hline
\end{tabular}

Values expressed as mean $\pm S D$. Values in the same row with different superscript letters indicate the significance $(p<0.05)$

with a ranged of health benefits including attenuation of carcinogenesis [58]. Mansara et al. also found that a low $\mathrm{n}-6 / \mathrm{n}-3$ ratio was associated with a decrease in cancer cell proliferation [59].

Our study has demonstrated that the FFA extract of krill oil showed similar anti-proliferative effects as that from fish oil except a slightly more krill oil extract is required to achieve the similar outcomes (Fig. 3). This may be attributed to the higher concentration of EPA in the fish oil. Animal studies are required to compare the anti-cancer effects of krill oil with fish oil given that studies have suggested that krill oil has a higher bioavailability than fish oil due to the unique chemical composition and thus the higher efficiency of fatty acid absorption into the blood [60].

This is the first study to report the pro-apoptotic effects of krill oil on human CRC cells. Although the mechanism is not clear, mitochondrial pathway seems to play a role. It is not known how EPA induced apoptosis at the present study. Krill oil contains a range of FFA including saturated fatty acids (SFA), monounsaturated fatty acids (MUFA) and polyunsaturated fatty acids (PUFA). It could be the synergistic effects of EPA with other fatty acids that resulted in the change of MMP. Taken together, these findings suggest that the proapoptotic properties of the krill oil extract may be associated with a complex mechanism, which requires further investigation on the interactions between the individual fatty acids in the oil and evaluation of molecular biomarkers involved in both the intrinsic and extrinsic pathways.

\section{Conclusion}

Krill oil extract has a pro-apoptotic effect on the human CRC cells HCT-15, SW-480 and Caco-2. Its antiproliferative role was also observed in HCT-15 and SW480 cells. EPA treatment showed similar health benefits 
as the FFA extract of krill oil. The FFA extract of krill oil induced the apoptosis of cancer cells may involve a mitochondria-mediated pathway. However, the apoptosis resulted from EPA treatment appears to be independent of the mitochondrial pathway. Further study is required to elucidate the complex mechanisms underlying the anti-cancer properties of krill oil extract. The outcomes of this study showed that krill oil may be protective against CRC as daily nutrient or as a conjunctive therapy for the CRC treatment.

\section{Acknowledgements}

Authors would like to thank Prof Andrew Sinclair for his advice on the methodology of FFA extraction from krill oil and fish oil. We also thank Mr Joseph Pelle for his assistance with Gas Chromatography.

\section{Funding}

Not applicable.

\section{Availability of data and materials}

The datasets supporting the conclusions of this article are included within the article.

\section{Authors' contributions}

XQS and PVS designed the study and critically revised the manuscript. AGJ collected and analysed the data, and drafted the manuscript. All authors read and approved the final manuscript.

\section{Competing interests}

The authors declare that they have no competing interests.

\section{Consent for publication}

Not applicable.

\section{Ethics approval and consent to participate}

Not applicable.

\author{
Author details \\ ${ }^{1}$ Centre for Chronic Disease, College of Health and Biomedicine, Victoria \\ University, P.O. Box 14428, Melbourne, VIC 8001, Australia. ${ }^{2}$ Melbourne \\ Medical School Western Campus, Western Centre for Health Research and \\ Education, Sunshine Hospital, St Albans, VIC 3021, Australia.
}

Received: 25 June 2016 Accepted: 23 August 2016

Published online: 30 August 2016

\section{References}

1. The American Cancer Society. Cancer Facts \& Figures 2014 http://www. cancer.org/research/cancerfactsstatistics/cancerfactsfigures [Accesed 1 Apr. 2015].

2. Jemal A, Bray F, Center MM, Ferlay J, Ward E, Forman D. Global cancer statistics. CA Cancer J Clin. 2011;61(2):69-90.

3. Binefa G, Rodriguez-Moranta F, Teule A, Medina-Hayas M. Colorectal cancer: from prevention to personalized medicine. World J Gastroenterol. 2014;20(22):6786-808.

4. Grady WM, Carethers JM. Genomic and epigenetic instability in colorectal cancer pathogenesis. Gastroenterology. 2008;135(4):1079-99.

5. Yang P, Cartwright C, Chan D, Ding J, Felix E, Pan Y, et al. Anticancer activity of fish oils against human lung cancer is associated with changes in formation of PGE2 and PGE3 and alteration of Akt phosphorylation. Mol Carcinog. 2014;53(7):566-77.

6. Granci V, Cai F, Lecumberri E, Clerc A, Dupertuis YM, Pichard C. Colon cancer cell chemosensitisation by fish oil emulsion involves apoptotic mitochondria pathway. Br J Nutr. 2013;109(7):1188-95.

7. Yao Q, Fu T, Wang LU, Lai Y, Wang Y, Xu C, et al. Role of autophagy in the omega-3 long chain polyunsaturated fatty acid-induced death of lung cancer A549 cells. Oncol Lett. 2015;9(6):2736-42.
8. Su X, Tanalgo P, Bustos M, Dass CR. The effect of krill Oil and n-3 polyunsaturated fatty acids on human osteosarcoma cell proliferation and migration. Curr Drug Targets. 2015;16:1-8.

9. de Rosa A, Gomez D, Hossaini S, Duke K, Fenwick SW, Brooks A, et al. Stage IV colorectal cancer: outcomes following the liver-first approach. J Surg Oncol. 2013;108(7):444-9.

10. Turk HF, Chapkin RS. Membrane lipid raft organization is uniquely modified by $\mathrm{n}-3$ polyunsaturated fatty acids. Prostaglandins Leukot Essent Fatty Acids. 2013;88(1):43-7.

11. Zhang C, Yu H, Ni X, Shen S, Das UN. Growth inhibitory effect of polyunsaturated fatty acids (PUFAs) on colon cancer cells via their growth inhibitory metabolites and fatty acid composition changes. PLoS One. 2015;10(4):e0123256.

12. Fahy B, Bold RJ. Epidemiology and molecular genetics of colorectal cancer. Surg Oncol. 1998;7(3-4):115-23.

13. Fasano E, Serini S, Piccioni E, Toesca A, Monego G, Cittadini AR, et al. DHA induces apoptosis by altering the expression and cellular location of GRP78 in colon cancer cell lines. Biochim Biophys Acta. 2012;1822(11):1762-72.

14. Xia $L$, Li MG. Effect of $n-3$ polyunsaturated fatty acids on proliferation and apoptosis of human colon cancer cell. Zhonghua Wei Chang Wai Ke Za Zhi. 2012;15(5):490-4.

15. Kuan CY, Walker TH, Luo PG, Chen CF. Long-chain polyunsaturated fatty acids promote paclitaxel cytotoxicity via inhibition of the MDR1 gene in the human colon cancer Caco-2 cell line. J Am Coll Nutr. 2011;30(4):265-73.

16. Kansal S, Bhatnagar A, Agnihotri N. Fish oil suppresses cell growth and metastatic potential by regulating PTEN and NF-kappaB signaling in colorectal cancer. PLoS One. 2014;9(1):e84627.

17. Fukui M, Kang KS, Okada K, Zhu BT. EPA. An omega-3 fatty acid, induces apoptosis in human pancreatic cancer cells: role of ROS accumulation, caspase8 activation, and autophagy induction. J Cell Biochem. 2013;114(1):192-203.

18. Cho Y, Turner ND, Davidson LA, Chapkin RS, Carroll RJ, Lupton JR. A chemoprotective fish oil/pectin diet enhances apoptosis via Bcl-2 promoter methylation in rat azoxymethane-induced carcinomas. Exp Bio Med. 2012;237(12):1387-93.

19. Bathen TF, Holmgren K, Lundemo AG, Hjelstuen MH, Krokan HE, Gribbestad IS, et al. Omega-3 fatty acids suppress growth of SW620 human colon cancer xenografts in nude mice. Anticancer Res. 2008;28(6A):3717-23.

20. Manna S, Chakraborty T, Ghosh B, Chatterjee M, Panda A, Srivastava S, et al. Dietary fish oil associated with increased apoptosis and modulated expression of Bax and BCl-2 during 7,12-dimethylbenz (alpha) anthraceneinduced mammary carcinogenesis in rats. Prostaglandins Leukot Essent Fatty Acids. 2008;79(1-2):5-14.

21. Winther B, Hoem N, Berge K, Reubsaet L. Elucidation of phosphatidylcholine composition in krill oil extracted from Euphausia superba. Lipids. 2011;46(1):25-36.

22. Tou JC, Jaczynski J, Chen YC. Krill for human consumption: nutritional value and potential health benefits. Nutr Rev. 2007;65(2):63-77.

23. Ramprasath VR, Eyal I, Zchut S, Jones PJ. Enhanced increase of omega-3 index in healthy individuals with response to 4-week n-3 fatty acid supplementation from krill oil versus fish oil. Lipids Health Dis. 2013;12:178.

24. Wijendran V, Huang MC, Diau GY, Boehm G, Nathanielsz PW, Brenna JT. Efficacy of dietary arachidonic acid provided as triglyceride or phospholipid as substrates for brain arachidonic acid accretion in baboon neonates. Pediatr Res. 2002:51(3):265-72.

25. Ulven SM, Kirkhus B, Lamglait A, Basu S, Elind E, Haider T, et al. Metabolic effects of krill oil are essentially similar to those of fish oil but at lower dose of EPA and DHA, in healthy volunteers. Lipids. 2011;46(1):37-46.

26. Zhu JJ, Shi JH, Qian WB, Cai ZZ, Li D. Effects of krill oil on serum lipids of hyperlipidemic rats and human SW480 cells. Lipids Health Dis. 2008;7:30-6.

27. Wong RS. Apoptosis in cancer: from pathogenesis to treatment. J Exp Clin Cancer Res. 2011;30:87.

28. Salimon J, Abdullah BM, Salih N. Hydrolysis optimization and characterization study of preparing fatty acids from Jatropha curcas seed oil. Chem Cent J. 2011;5:67.

29. Lepage G, Roy CC. Direct transesterification of all classes of lipids in a one-step reaction. J Lipid Res. 1986;27(1):114-20.

30. Ikeda K, Myotoku M, Hirotani Y. Characterization of multidrug resistanceassociated protein mRNAs expression profiles in Caco-2 and HT-1080 cell lines induced by methotrexate. Pharmazie. 2008;63(12):883-9.

31. Luk F, Yu Y, Walsh WR, Yang JL. IGF1R-targeted therapy and its enhancement of doxorubicin chemosensitivity in human osteosarcoma cell lines. Cancer Invest. 2011;29(8):521-32. 
32. Zhang C, Yu H, Shen Y, Ni X, Shen S, Das UN. Polyunsaturated fatty acids trigger apoptosis of colon cancer cells through a mitochondrial pathway. Arch Med Sci. 2015;11(5):1081-94.

33. Vaughan VC, Hassing MR, Lewandowski PA. Marine polyunsaturated fatty acids and cancer therapy. Br J Cancer. 2013;108(3):486-92.

34. Chiu LC, Ooi VE, Wan JM. Eicosapentaenoic acid modulates cyclin expression and arrests cell cycle progression in human leukemic K-562 cells. Int J Oncol. 2001;19(4):845-9.

35. Clarke RG, Lund EK, Latham P, Pinder AC, Johnson IT. Effect of eicosapentaenoic acid on the proliferation and incidence of apoptosis in the colorectal cell line HT29. Lipids. 1999;34(12):1287-95.

36. Courtney ED, Matthews S, Finlayson C, Di Pierro D, Belluzzi A, Roda E, et al. Eicosapentaenoic acid (EPA) reduces crypt cell proliferation and increases apoptosis in normal colonic mucosa in subjects with a history of colorectal adenomas. Int J Colorectal Dis. 2007;22(7):765-76.

37. Corsetto PA, Montorfano G, Zava S, Jovenitti IE, Cremona A, Berra B, et al. Effects of n-3 PUFAs on breast cancer cells through their incorporation in plasma membrane. Lipids Health Dis. 2011;10:73.

38. Larsson SC, Kumlin M, Ingelman-Sundberg M, Wolk A. Dietary long-chain n-3 fatty acids for the prevention of cancer: a review of potential mechanisms. Am J Clin Nutr. 2004;79(6):935-45.

39. Schmitz G, Ecker J. The opposing effects of n-3 and n-6 fatty acids. Prog Lipid Res. 2008;47(2):147-55.

40. Lai PB, Ross JA, Fearon KC, Anderson JD, Carter DC. Cell cycle arrest and induction of apoptosis in pancreatic cancer cells exposed to eicosapentaenoic acid in vitro. Br J Cancer. 1996;74(9):1375-83.

41. Chiu LC, Tong KF, Ooi VE. Synergistic action of piroxicam on the eicosapentaenoic acid-induced apoptosis is associated with enhanced down-regulation of anti-apoptotic $\mathrm{BCl}-2$ expression but not promoted activation of pro-apoptotic bid protein. Oncol Rep. 2004;11(1):225-30.

42. Chi TY, Chen GG, Lai PB. Eicosapentaenoic acid induces Fas-mediated apoptosis through a p53-dependent pathway in hepatoma cells. Cancer J. 2004;10(3):190-200.

43. Piazzi G, D'Argenio G, Prossomariti A, Lembo V, Mazzone G, Candela M, et al. Eicosapentaenoic acid free fatty acid prevents and suppresses colonic neoplasia in colitis-associated colorectal cancer acting on Notch signaling and gut microbiota. Int J Cancer. 2014;135(9):2004-13.

44. Heimli H, Giske C, Naderi S, Drevon CA, Hollung K. Eicosapentaenoic acid promotes apoptosis in Ramos cells via activation of caspase-3 and -9 . Lipids. 2002;37(8):797-802.

45. Arita K, Kobuchi H, Utsumi T, Takehara Y, Akiyama J, Horton AA, et al. Mechanism of apoptosis in HL-60 cells induced by n-3 and n- 6 polyunsaturated fatty acids. Biochem Pharmacol. 2001;62(7):821-8.

46. Colquhoun A, Schumacher RI. Gamma-Linolenic acid and eicosapentaenoic acid induce modifications in mitochondrial metabolism, reactive oxygen species generation, lipid peroxidation and apoptosis in Walker 256 rat carcinosarcoma cells. Biochim Biophys Acta. 2001;1533(3):207-19.

47. Sharma G, Rani I, Kansal S, Bhatnagar A, Agnihotri N. Alterations in mitochondrial membrane in chemopreventive action of fish oil. Cancer Invest. 2013;31(4):231-40.

48. Hong MY, Chapkin RS, Barhoumi R, Burghardt RC, Turner ND, Henderson CE, et al. Fish oil increases mitochondrial phospholipid unsaturation, upregulating reactive oxygen species and apoptosis in rat colonocytes. Carcinogenesis. 2002;23(11):1919-25.

49. Hongmei Z. Extrinsic and Intrinsic apoptosis Signal Pathway review. Biochemistry GaMb, editor: Tobias M. Ntuli; 2012. Chapter 1.

50. Jeong S, Jing K, Kim N, Shin S, Kim S, Song KS, et al. Docosahexaenoic acid-induced apoptosis is mediated by activation of mitogen-activated protein kinases in human cancer cells. BMC Cancer. 2014;14(1):1-11.

51. Shin S, Jing K, Jeong S, Kim N, Song KS, Heo JY, et al. The omega-3 polyunsaturated fatty acid DHA induces simultaneous apoptosis and autophagy via mitochondrial ROS-mediated Akt-mTOR signaling in prostate cancer cells expressing mutant p53. Biomed Res Int. 2013;2013:1-11.

52. Schonberg SA, Lundemo AG, Fladvad T, Holmgren K, Bremseth H, Nilsen A, et al. Closely related colon cancer cell lines display different sensitivity to polyunsaturated fatty acids, accumulate different lipid classes and downregulate sterol regulatory element-binding protein 1. FEBS J. 2006;273(12):2749-65.

53. Giros A, Grzybowski M, Sohn VR, Pons E, Fernandez-Morales J, Xicola RM, et al. Regulation of colorectal cancer cell apoptosis by the n-3 polyunsaturated fatty acids Docosahexaenoic and Eicosapentaenoic. Cancer Prev Res. 2009;2(8):732-42.

54. Cockbain AJ, Toogood GJ, Hull MA. Omega-3 polyunsaturated fatty acids for the treatment and prevention of colorectal cancer. Gut. 2012:61(1):135-49.

55. Irwin ME, Mueller KL, Bohin N, Ge Y, Boerner JL. Lipid raft localization of EGFR alters the response of cancer cells to the EGFR tyrosine kinase inhibitor gefitinib. J Cell Physiol. 2011;226(9):2316-28.

56. Chapkin RS, McMurray DN, Lupton JR. Colon cancer, fatty acids and antiinflammatory compounds. Curr Opin Gastroenterol. 2007;23(1):48-54.

57. Calviello G, Palozza P, Maggiano N, Piccioni E, Franceschelli P, Frattucci A, et al. Cell proliferation, differentiation, and apoptosis are modified by n-3 polyunsaturated fatty acids in normal colonic mucosa. Lipids. 1999;34(6):599-604.

58. Mateos HT, Lewandowski PA, Vaughan VC, Su X. Health impacts of eicosapentaenoic acid and docosahexaenoic acid. CAB Reviews. 2013;8(7):1-12.

59. Mansara PP, Deshpande RA, Vaidya MM, Kaul-Ghanekar R. Differential Ratios of Omega Fatty Acids (AA/EPA + DHA) Modulate Growth, Lipid Peroxidation and Expression of Tumor Regulatory MARBPs in Breast Cancer Cell Lines MCF7 and MDA-MB-231. PLoS One. 2015;10(9):e0136542.

60. Cicero AF, Colletti A. Krill oil: evidence of a new source of polyunsaturated fatty acids with high bioavailability. Clin Lipidol. 2015;10(1):1-4.

\section{Submit your next manuscript to BioMed Central and we will help you at every step:}

- We accept pre-submission inquiries

- Our selector tool helps you to find the most relevant journal

- We provide round the clock customer support

- Convenient online submission

- Thorough peer review

- Inclusion in PubMed and all major indexing services

- Maximum visibility for your research

Submit your manuscript at www.biomedcentral.com/submit
Ciomed Central 